\title{
PERSEPSI WISATAWAN TERHADAP KUALITAS PELAYANAN PRAMUWISATA DI BALI
}

\author{
Ida Bagus Putu Saskara Putra \\ I Made Kusuma Negara \\ Ni Made Sofia Wijaya \\ Email : putrasaskara@yahoo.com \\ PS. S1 Industri Perjalanan Wisata \\ Fakultas Pariwisata UNUD
}

\begin{abstract}
Tour guide has an importan role in tourism activities. It can be seen from the function of a tour guide as such are conduits for privileged 'inside' information on the tourist destination. The purpose of this study is to find out how the tourist perception to the quality service of tour guide in Bali.Data collection techniques used in this research is a questionnaire and literature study for determine this sample was using purposive sampling by gave questionnaires to 400 respondents. The data was analysis used descriptive quantitative. There are two types of respondents, domestic tourists numbered 263 respondents and foreign tourists numbered 137 respondents, each divided according to the proportional 0.05. This study used five variables and consists of twenty indicators.Data collection techniques used in this research is questionnaires and literature study. In determining the sample was using purposive sampling by distributed questionnaires to 400 respondents. Data analysis techniques used in descriptive quantitative. There are two types of respondents domestic tourists amounted to 263 respondents and foreign tourists numbered 137 respondents, each divided according to the proportional 0.05. This study uses five variables and consists of twenty indicators. The results of this research is the tourist perception overall consisting of domestic and foreign tourists can be concluded, tourists perception of the tour guides service quality in Bali is already very good.
\end{abstract}

Keywords: Tourist Perception, Quality of Services, Tour Guide.

\section{PENDAHULUAN}

Pulau Bali merupakan salah satu destinasi andalan yang tiap tahunnya mampu menarik banyak wisatawan untuk melakukan perjalanan wisata.Bali sudah sangat dikenal wisatawan baik keindahan pantainya, keunikan budayanya, maupun keramahan masyarakatnya yang mampu menarik wisatawan agar mengunjungi Pulau Dewata ini.Selain itu, banyak jenis wisata yang bisa dilakukan di Pulau Bali, hal ini juga menjadi salah satu alasan mengapa wisatawan tidak pernah bosan untuk berkunjung.

Pramuwisata merupakan salah satu bagian penting yang selalu terlibat dalam kegiatan kepariwisataan.Itu dapat dilihat dari fungsi seorang pramuwisata yang menjadi pemberi informasi dan pemandu wisata yang diperlukan wisatawan dalam melakukan perjalanan wisata. Seorang wisatawan pasti sangat memerlukan pramuwisata karena wisatawan melakukan perjalanan ke daerah asing, sudah tentu mereka belum banyak mengetahui daerah tujuannya, untuk mempermudah perjalanan seorang wisatawan maka diperlukan seorang pramuwisata yang sudah sangat mengetahui daerah tujuan yang akan dikunjungi wisatawan. Pada Tabel 1 merupakan jumlah pramuwisata Bali menurut divisi bahasa.

Gubernur Bali mengatakan bahwa banyak pramuwisata yang belum mampu memahami persis budaya Bali, bahkan ada yang tidak berlisensi.Ada juga yang kesulitan dalam penguasaan bahasa Mandarin dan Rusia. Beberapa kelemahan itu harus diperbaiki(Rhismawati, 2016). Ini membuktikan bahwa pramuwisata Bali masih 
memiliki beberapa kekurangan yang perlu diperhatikan.Ketua DPRD Bali Nyoman Adi Wiryatama mengatakan, pramuwisata merupakan garda depan pariwisata Bali. "Pernah Pura Tirta Empul dibilang kuburan, dalam bahasa Jepangnya dia bilang hakaonaji (apakah sama, red) dengan ohaka (kuburan, red), hai onaji (iya sama)", artinya sama dengan kuburan, padahal itu Pura Tirta Empul kan tidak kuburan," keluh mantan Bupati Tabanan ini. "Karena pramuwisata tidak memiliki pemikiran yang cukup, maka itulah perlu adanya revisi peraturan agar bisa kita mengawasi dan membina mereka. Pramuiwisata Bali ini harus bisa menerima dan betul-betul paham wisata Bali ini" (Wahyura, 2016). Dari kuitipan diatas dapat dilihat bahwa pramuwisata Bali masih ada yang melakukan kesalahan dalam menjelaskan suatu destinasi wisata.

Tabel 1. Jumlah Pramuwisata Bali Menurut Divisi BahasaTahun 2016

\begin{tabular}{llr}
\hline No & Bahasa & Jumlah \\
\hline 1 & Domestik & 329 \\
2 & Inggris & 780 \\
3 & Jepang & 710 \\
4 & Mandarin & 470 \\
5 & Rusia & 70 \\
6 & Prancis & 180 \\
7 & Jerman & 175 \\
8 & Korea & 457 \\
9 & Italia & 50 \\
10 & Belanda & 66 \\
Total & & 3287 \\
\hline
\end{tabular}

Sumber: Himpunan Pramuwisata Indonesia, Bali, 2016

Kebijakan bebas visa yang berlaku untuk wisatawan mancanegara dari 169 negara juga mulai meresahkan. Selain kedatangan wisman yang tidak berkualitas, kini kemunculan guide asing di Bali pun dinilai meresahkan. "Guide asing ini merugikan pramuwisata lokal," kata Kadis Pariwisata Bali, AA Gede Yuniartha Putra. "Saya sering melihat langsung. Saya juga banyak mendapat laporan terutama guide China di Restoran Akame, Benoa dan juga di mall Benoa," ungkapnya. Bahkan ia juga berani memastikan bahwa yang ia temukan merupakan guide China karena yang bersangkutan menggerakkan banyak orang saat masuk mobil
(Nv, 2017). Dengan kemunculan guide asing yang terdapat di Bali maka pramuwisata lokal memiliki pesaing yang perlu diperhatikan.

Kualitas pelayanan pramuwisata sangat menentukan apakah wisatawan puas atau tidak dengan pelayanan yang diberikan.Pendapat wisatawan sangat diperlukan untuk mengembangkan kualitas pramuwisata Bali agar kedepannya pramuwisata Bali bisa memberikan pelayanan yang semakin baik. Oleh sebab itu perlu adanya penilaian akan kualitas pramuwisata di Bali, apakah sudah baik atau malah buruk. Jika kita melihat peran pramuwisata yang menjadi ujung tombak pariwisata dalam menjaga dan meningkatkan citra suatu destinasi wisata, dan juga berdasarkan pemberitaan dari beberapa media masa mengenai kualitas pelayanan pramuwisata, maka sangat diperlukan untuk mengetahui bagaimana persepsi wisatawan mengenai kualitas pelayanan yang diberikan oleh pramuwisata di Bali. Untuk mengukur itu maka diperlukanlah wisatawan yang menjadi penilai sebagai pengguna jasa pramuwsiata.Berdasarkan latar belakang tersebut maka penulis meneliti mengenai "Persepsi Wisatawan Terhadap Kualitas Pelayanan Pramuwisata di Bali”.

\section{METODE}

Sampel lokasi yang akan digunakan untuk penyebaran kuisioner dilakukan di tiga daya tarik wisata yang paling banyak dikunjungi wisatawan di Bali yaitu Tanah Lot, Uluwatu, dan Ulun Danu Beratan. Sedangkan devinisi operasional variabel yang digunakan yaitu kualitas pelayanan. Teori kualitas pelayanan yang digunakan adalah teori Kotler (2005) yaitu mengidentifikasi lima dimensi pokok yang dapat mempengaruhi dan menentukan kualitas jasa, yaitu berwujud (tangible), penampilan, keterampilan, kebersihan, dan media komunikasi.Empati (emphaty), memberikan perhatian, peduli serta kemampuan dalam memahami kebutuhan pelanggan.Responsive (responsivenes), ketanggapan atau kesigapan dalam memberikanpelayanan.Keandalan (reliability), kemampuan dalam melaksanakan jasa yang dijanjikan dengan tepat dan terpecaya.Keyakinan (assurance), kemampuan untuk memberikan pengetahuan dan kesopanan serta keyakinan dalam memberikan pelayanan. Jenis data yang digunakan yaitu 
data kuantitatif dan data kualitatif. Sedangkan sumber data yang digunakan yaitu data primer dan data skunder.

Teknik penentuan sampel yang digunakan yaitu purposive samplin, adalah metode penentuan sampel dengan pertimbangan tertentu (Sugiyono, 2015).Sedangkan teknik pengambilan sampel yaituproposional stratified sampling, Teknik ini digunakan bila populasi mempunyai anggota/unsur yang tidak homogen dan berstratan secara proposional (Sugiyono, 2015).Lalu untuk menentukan jumlah responden menggunakan metode slovin, digunakan untuk menentukan ukuran sampel dari populasi yang rata-ratanya telah diketahui jumlahnya. Jumlah sampel yang digunakan yaitu 400 responden dan dibagi menjadi dua jenis wisatawan domestik 263 responden dan wisatawan mancanegara 137 responden. Teknik pengumpulan data yang digunakan yaitu kuisioner dan studi kepustakaan metode kuisioner yang digunakan yaitu skala likert. Metode analisis data yang digunakan yaitu deskriptif kuantitatif.

HASIL

Persepsi Wisatawan Domestik terhadap Kualitas Pelayanan Pramuwisata di Bali yaitu terdapat 5 variabel yang pertama variabel berwujud (tangible) dengan hasilpesepsi wisatawan domestik yang berjumlah 263 responden terhadap 4 indikator. indikator yang pertama yaitu kebersihan dan kerapian pramuwisata mendapatkan rata-rata skor sebesar 4,65 dan dapat dikategorikan sangat baik. Lalu dilanjutkan dengan indikator sikap pramuwisata saat berbicara mendapatkan ratarata skor sebesar 4,66 dan dapat dikategorikan sangat baik.Dilanjutkan dengan indikator adanya sambutan awal dari pramuwisata yang mendapatkan rata-rata skor sebesar 4,63 dan dapat dikategorikan sangat baik. Yang terakhir indikator pramuwisata berbicara disaat wisatawan tidak sibuk dengan hal yang lain mendapatkan rata-rata skor sebesar 4,12 dan dapat dikategorikan baik. Dari hasil tersebut didapatkan total skor dari keempat indikator tersebut sebesar 18,6 dengan rata-rata 4,51. Selanjutnya variabel empati (emphaty) dengan hasil persepsi wisatawan domestik yang berjumlah 263 responden terhadap 4 indikator yang pertama yaitu indikator pramuwisata memberikan perhatian lebih kepada wisatawan dengan rata-rata skor 4,35 dengan kategori sangat baik. Selanjutnya indikator mendengarkan keluhan wisatawan dengan rata-rata skor sebesar 4,22 dan dapat dikategorikan sangat baik.Lalu indikator menanggapi keluhan wisatawan mendapatkan rata-rata skor sebesar 4,45 dengan kategori sangat baik.Dan yang terakhir indikator tersenyum dan ramah ketika melayani wisatawan mendapatkan rata-rata skor sebesar 4,51 dan dapat dikategorikan sangat baik. Selanjutnya variabel responsive (responsivenes) dengan hasil dari persepsi wisatawan domestik yang berjumlah 263 responden terhadap 3 indikator, yang pertama yaitu indikator tindakan cepat pramuwisata dalam memberikan pelayanan terhadap wisatawan mendapatkan rata-rata skor sebesar 4,52 dengan kategori sangat baik. Selanjutnya indikator kemampuan pramuwisata dalam memahami kebutuhan wisatawan dengan ratarata skor sebesar 4,42 dan mendapatkan kategori sangat baik.Lalu indikator pramuwisata tanggap ketika dibutuhkan wisatawan mendapatkan skor sebesar 4,38 dengan kategori sangat baik. Lalu variabel keandalan (reliability) dengan hasil persepsi wisatawan domestik mengenai lima indikator, yang pertama yaitu indikator kemampuan berkomunikasi pramuwisata mendapatkan rata-rata skor sebesar 4,58 dengan kategori sangat baik. Selanjutnya indikator memberikan informasi yang jelas oleh pramuwisata mendapatkan rata-rata skor sebesar 4,59 dengan kategori sangat baik.Lalu indikator memberikan kesan baik terhadap suatu daya tarik wisata dengan rata-rata skor sebesar 4,60 dan mendapatkan kategori sangat baik. Selanjutnya indikator pramuwisata tidak mencemarkan nama baik perusahaan, teman seprofesi, dan unsur-unsur pariwisata lainnya mendapatkan rata-rata skor 4,62 dengan kategori sangat baik. Dan yang terakhir yaitu indikator pramuwisata tidak menceritakan masalah pribadinya mendapatkan rata-rata skor sebesar 4,62 dengan kategori sangat baik. Dan yang terakhir variabel keyakinan (assurance) dengan hasilpersepsi wisatawan terhadap 4 indikator, yang pertama yaitu indikator wisatawan percaya terhadap pramuwisata mendapatkan rata-rata skor sebesar 4,40 dengan kategori sangat baik, sedangkan indikator kesopanan pramuwisata dalam memberikan pelayanan mendapatkan rata-rata skor sebesar 4,56 dengan kategori sangat baik. Lalu indikator pramuwisata 
mampu memberikan rasa aman dan mampu meningkatkan kepercayaan wisatawan mendapatkan rata-rata skor sebesar 4,55 dengan kategori sangat baik. Dan yang terakhir indikator pramuwisata tidak meminta tip kepada wisatawan mendapatkan rata-rata skor sebesar 4,57 dengan kategori sangat baik.

\section{Persepsi Wisatawan Mancanegara terhadap Kualitas Pelayanan Pramuwisata Di Bali} yaitu terdapat 5 variabel yang pertama variabel berwujud (tangible) dengan hasil dilihat persepsi wisatawan mancanegara terhadap 4 indikator yang pertama yaitu kebersihan dan kerapian pramuwisata yang mendapatkan ratarata skor sebesar 4,64 dan dapat dikategorikan sangat baik. Lalu dilanjutkan dengan indikator sikap pramuwisata dengan rata-rata skor sebesar 4,62 dengan kategori sangat baik.Selanjutnya indikator adanya sambutan awal dari pramuwisata mendapatkan rata-rata skor 4,63 dengan kategori sangat baik. Dan yang terakhir yaitu indikator pramuwisata berbicara disaat wisatawan tidak sibuk dengan hal yang lain mendapatkan rata-rata skor sebesar 4,54 dengan kategori sangat baik. Selanjutnya variabel empati (emphaty) dengan hasil persepsi wisatawan mancanegara terhadap 4 indikator variabel empati (emphaty), yang pertama yaitu indikator pramuwisata memberikan perhatian lebih kepada wisatawan mendapatkan rata-rata skor sebesar 3,43 dan mendapatkan kategori baik. Lalu selanjutnya indikator mendengarkan keluhan wisatawan dengan rata-rata skor sebesar 4,57 dengan kategori sangat baik.Kemudian indikator menanggapi keluhan wisatawan mendapatkan rata-rata skor sebesar 4,61 dengan kategori sangat baik. Lalu variabel responsive (responsivenes) dengan hasil persepsi wisatawan mancanegara terhadap tiga indikator yang pertama yaitu tindakan cepat pramuwisata dalam memberikan pelayanan terhadap wisatawan mendapatkan rata-rata skor sebesar 4,40 dengan kategori baik. Selanjutnya indikator kemampuan pramuwisata dalam memahami kebutuhan wisatawan mendapatkan rata-rata skor sebesar 4,27 dengan kategori sangat baik.Dan yang terakhir yaitu indikator pramuwisata tanggap ketika dibutuhkan wisatawan mendapatkan rata-rata skor sebesar 4,20 dengan kategori baik. Selanjutnya variabel keandalan (reliability) dengan hasilpersepsi wisatawan mancanegara terhadap lima indikator, yang pertama yaitu kemampuan berkomunikasi pramuwisata dengan rata-rata skor sebesar 4,13 dan mendapatkan kategori baik. Lalu selanjutnya indikator memberikan informasi yang jelas oleh pramuwisata dengan rata-rata skor sebesar 4,56 dengan kategori sangat baik.Selanjutnya indikator memberikan kesan baik terhadap suatu daya tarik wisata dengan rata-rata skor sebesar 4,60 dan mendapatkan kategori sangat baik. Kemudian indikator pramuwisata tidak mencemarkan nama baik prusahaan, teman seprofesi, dan unsur-unsur pariwisata lainnya dengan rata-rata sekor sebesar 4,62 dan mendapatkan kategori sangat baik. Dan yang terakhir indikator pramuwisata tidak menceritakan masalah pribadinya yang mendapatkan rata-rata skor sebesar 4,61 dan mendapatkan kategori sangat baik. Dan yang terakhir variabel keyakinan (assurance) dengan hasil persepsi wisatawan mancanegara terhadap 4 indikator, yang pertama yaitu wisatawan percaya terhadap pramuwisata dengan rata-rata skor sebesar 4,65 dan mendapatkan kategori sangat baik. Lalu selanjutnya indikator kesopanan pramuwisata dalam memberikan pelayanan dengan rata-rata skor sebesar 4,60 dan mendapatkan kategori sangat baik.Kemudian indikator pramuwisata mampu memberikan rasa aman dan mampu meningkatkan kepercayaan wisatawan dengan rata-rata skor sebesar 4,62 mendapatkan kategori sangat baik. Dan yang terakhir indikator pramuwisata tidak meminta tip kepada wisatawan dengan rata-rata skor sebesar 4,64 dan mendapatkan kategori sangat baik.

Persepsi Wisatawan terhadap Kualitas Pelayanan Pramuwisata Secara Simultan Di Bali Terdapat total 20 indikator untuk menilai kualitas pelayanan pramuwisata Bali. Indikator yang mendapatkan skor paling tinggi yaitu sikap pramuwisata dengan skor sebesar 4,65.Itu artinya wisatawan menilai sikap pramuwisata Bali sudah sangat baik.Sedangkan indikator yang mendapatkan skor paling rendah yaitu indikator pramuwisata memberikan perhatian lebih kepada wisatawan dengan skor 4,24 dan ini masih bisa dikategorikan sangat baik. Artinya wisatawan menilai pramuwisata Bali sudah sangat baik dalam memperhatikan wisatawan, akan tetapi masih bisa ditingkatkan. Dari keseluruhan skor yang didapatkan terhadap 20 
indikator pada Tabel 4.16 didapatkan total skor sebesar 90,5 dan rata-rata sebesar 4,52 dengan kategori sangat baik.

\section{PEMBAHASAN}

Persepsi wisatawan domestik terhadap kualitas pelayanan pramuwisata di Bali ratarata sudah sangat baik. Dapat dilihat dari hasil penelitian yang menunjukan persepsi wisatawan sangat baik. Akan tetapi masih terdapat kekurangan di beberapa indikator dengan masih banyaknya responden yang menyatakan cukup. Seperti indikator pramuwisata berbicara disaat wisatawan tidak sibuk dengan hal lain yang mendapatkan 63 persepsi cukup dari wisatawan, sehingga hanya mendapatkan kategori baik. Artinya masih ada pramuwisata yang berbicara pada saat wisatawan sibuk atau memperhatikan hal lain sehingga informasi yang diberikan tidak didengarkan. Pada indikator mendengarkan keluhan wisatawan juga terdapat 60 persepsi cukup dari wisatawan. Artinya masih ada pramuwisata yang tidak terlalu memperdulikan keluhan wisatawan. Akan tetapi dari total 5 variabel semua mendapatkan rata-rata sangat baik dan itu menunjukan bahwa pramuwisata Bali memiliki kualitas yang baik di mata wisatawan domestik

Persepsi wisatawan mancanegara terhadap pramuwisata di Bali rata-rata sudah sangat baik. Dari total 5 variabel semua mendapatkan rata-rata yang sangat baik. Adapun kekurangan yang perlu diperhatikan yaitu pada indikator pramuwisata memberikan perhatian lebih kepada wisatawan yang mendapatkan skor sbesar 3,43 dengan kategori baik. Artinya pada indikator ini masih perlu adanya peningkatan. Selanjutnya pada indikator pramuwisata tanggap ketika dibutuhkan wisatawan dengan skor 4,20 mendapatkan kategori baik. dengan hasil tersebut artinya indikator ini masih bisa ditingkatkan lagi agar semakin baik. Lalu indikator tersenyum dan ramah ketika melayani wisatawan. Indikator tersebut mendapatkan 53 persepsi cukup dari wisatawan, artinya beberapa pramuwisata dinilai tidak ramah ketika melayani wisatawan.

Persepsi wisatawan terhadap kualitas pelayanan pramuwisata secara simultan di Bali rata-rata sudah sangat baik. dari total 5 variabel dan 20 indikator semua mendapatkan skor sangat baik. adapun indikator yang mendapatkan skor tertinggi yaitu sikap pramuwisata yang mendapatkan total skor sebesar 4,65 dengan kategori sangat baik. sedangkan indikator yang mendapatkan total skor terendah yaitu pramuwisata memberikan perhatian lebih kepada wisatawan yang mendapatkan skor 4,24 dengan kategori sangat baik.

\section{SIMPULAN DAN SARAN Simpulan}

Dari hasil penelitian terhadap wisatawan domestik sebagai responden dapat disimpulkan bahwa, persepsi wisatawan domestik terhadap kualitas pelayanan pramuwisata di Bali adalah sangat baik. Ada satu indikator yang masih bisa ditingkatkan seperti indikator pramuwisata berbicara disaat wisatawan tidak sibuk dengan hal lain yang hanya mendapatkan kategori baik. Dan selebihnya persepsi wisatawan domestik terhadap kualitas pelayanan pramuwisata di Bali sudah sangat baik.

Sedangkan dari hasil penelitian terhadap wisatawan mancanegara sebagai responden dapat disimpulkan bahwa, persepsi wisatawan mancanegara terhadap kualitas pelayanan pramuwisata di Bali adalah sangat baik. Ada beberapa indikator yang masih bisa ditingkatkan seperti memberikan perhatian lebih kepada wisatawan, kemampuan berkomunikasi dan ketanggapan pramuwisata dalam bertindak yang hanya mendapatkan kategori baik.

Hasil penelitian terhadap wisatawan secara simultan, yaitu persepsi wisatawan secara keseluruhan baik itu wisatawan domestik dan mancanegara dapat disimpulkan bahwa, persepsi wisatawan terhadap kualitas pramuwisata di Bali adalah sangat baik.

\section{Saran}

Dari hasil penelitian ini, terdapat beberapa saran yang dapat diberikan kepada pramuwisata Bali yaitu, tetap mempertahankan kualitas pelayanan yang sudah ada dan juga meningkatkan kualitas di beberapa sektor seperti memperhatikan wisatawan saat pramuwisata ingin menyampaikan informasi penting, perhatikan wisatawan apakah sedang sibuk atau tidak agar wisatawan nyaman mendengarkan informasi yang akan diberikan. Selanjutnya meningkatkan kemampuan berkomunikasi pramuwisata dan yang terakhir pramuwisata harus lebih tanggap dalam bertindak ketika melayani wisatawan.Hal 
tersebutlah yang harus ditingkatkan sehingga untuk kedepannya kualitas pelayanan pramuwisata Bali mampu menjadi lebih baik lagi.

\section{DAFTAR PUSTAKA}

Annonim. 2016. Jumlah Pramuwisata Bali. http://hpibali.org/. Diakses tanggal 28-Mei-2016

Fandy Tjiptono. 2007. Pemasaran Jasa. Bayumedia. Malang

Husaini. 2006. Pengantar Statistika. Jakarta: Bumi Aksara.
Karyono. 1997. Kepariwisataan. Jakarta: Grasindo

Kotler, Philip. 2005. Manajamen Pemasaran, Jilid 1 dan 2. Jakarta: PT. Indeks. Kelompok Gramedia.

Sugiyono. 2015. Metode Penelitian Kuantitatif, Kualitatif, Dan $R \& D$. Bandung: Alfabeta

Suwantoro, Gamal. 2002. Dasar-Dasar Pariwisata. Yogyakarta: Andi. Offset.

Yoeti. 1995. Pengantar Ilmu Kepariwisataan. Yogyakarta:Erlang 